\title{
PEMBERDAYAAN MASYARAKAT MELALUI PEMBUATAN PUPUK CAIR DI DESA WANAYASA KAPUPATEN PURWAKARTA
}

\author{
Yuyun Yuningsih, Sumardani, Umi Hani \\ Universitas Pasundan \\ yuyun.yuningsih@unpas.ac.id Sumardani@unpas.ac.id Umihani@unpas.ac.id
}

\begin{abstract}
ABSTRAK
Pelaksanaan pemberdayaan masyarakat berupa transfer teknologi tentang pembuatan pupuk cair merupakan upaya untuk memanfaatkan potensi lingkungan sekitar berupa sisa sampah organik. Kegiatan ini dilaksanakan di Desa Wanayasa Kecamatan Wanayasa Kabupaten Purwakarta. Metode yang digunakan dalam kegiatan ini yaitu pemberian materi dan demonstrasi. Pemberian materi tentang berbagai bahan sisa sampah organik disekitar lingkungan Desa Wanayasa yang dapat digunakan sebagai sumber bahan baku pembuatan pupuk cair. Demonstrasi dilakukan dengan melakukan praktik pembuatan pupuk cair dengan menggunakan bahan baku hijauan, dedaunan, jatuhan buah-buahan yang ada disekitar lingkungan Desa Wanayasa, yang langsung di pandu oleh tenaga ahli dari Dinas Lingkungan Hidup dan Kebersihan Kota Bandung (DLHK). Transfer teknologi pembuatan pupuk cair memberikan manfaat yang besar yaitu adanya peningkatan pengetahuan warga tentang manfaat bahan sisa sampah organik sebagai bahan baku pembuatan pupuk cair, kesadaran akan kesehatan lingkungan juga semakin baik serta memberikan nilai ekonomis bagi warga, karena mengurangi pengeluaran pembelian pupuk bagi petani dan bisa menambah penghasilan keluarga dari penjualan pupuk cair.
\end{abstract}

Kata kunci: pemberdayaan masyarakat, transfer teknologi, sampah organik, pupuk cair.

\section{ABSTRACT}

The implementation of community empowerment in the form of technology transfer about making liquid is an effort to utilize the potential of the surrounding environment in the form of residual organic waste. This activity was held in Wanayasa Village, Wanayasa Subdistrict, Purwakarta District. The method used in this activity is the provision of material and demonstrations. Giving material about various organic waste material around the village of Wanayasa that can be used as a source of raw material for making liquid fertilizer. The demonstration was carried out by practicing the making of liquid fertilizers using forage / foliage raw materials, banana humps, and many which were found around Wanayasa Village, which was directly guided by experts from the Bandung City Environmental and Hygiene Agency (DLHK). The transfer of liquid fertilizer production technology provides a great benefit, namely an increase in people's knowledge about the benefits of organic waste as raw material for making liquid fertilizer, environmental health awareness is also getting better and providing economic value to residents, because it reduces the purchase of fertilizer for farmers and can increase family income from the sale of liquid fertilizer.

Keywords: community empowerment, technology transfer, organic waste, liquid fertilizer. 


\section{PENDAHULUAN}

Desa Wanayasa memiliki sejarah yang cukup tua, bahkan lebih tua dari kabupaten induknya sekarang, yaitu kabupaten Purwakarta. Saat ini desa Wanayasa merupakan desa kecil, namun keberadaanya didukung dengan letak geografis yang sangat strategis dengan potensi yang dimilikinya berupa situ Wanayasa yang menjadi tempat wisata yang banyak dikunjungi oleh wisatawan domestik dan wisatawan luar negeri. Namun potensi tersebut tidak didukung oleh kesadaran masyarakat akan kebersihan lingkungan, banyak sampah yang dibuang tidak pada tempatnya, sehingga membuat lingkungan menjadi tidak bersih dan sehat. Berdasarkan penomena dan fakta tersebut maka dilakukan upaya pemberdayaan masyarakat dalam mengelola sampah dalam bentuk pengabdian masyarakat dengan memberikan pelatihan pembuatan pupuk cair. Dengan pelatihan tersebut diharapkan masyarakat memperoleh beberapa manfaat, yang pertama: menjadikan lingkungan menjadi bersih, kedua; kesadaran masyarakat terhadap kesehatan lingkungan menjadi meningkat dan yang ke tiga: memiliki nilai ekonomis bagi masyarakat.

Pemberdayaan masyarakat pada intinya merupakan cara yang dilakukan untuk meningkatkan kemampuan masyarakat demi kemajuan masyarakat itu sendiri ke arah yang lebih baik melalui kegiatan-kegiatan yang dapat membantu kualitas diri masyarakat agar berkembang dan tidak terbelakang. Dalam upaya memberdayakan masyarakat dapat dilihat dari tiga sisi, yaitu (Sumodiningrat, Gunawan, 2002) ; pertama, menciptakan suasana atau iklim yang memungkinkan potensi masyarakat berkembang (enabling). Disini titik tolaknya adalah pengenalan bahwa setiap manusia, setiap masyarakat, memiliki potensi yang dapat dikembangkan. Kedua, memperkuat potensi atau daya yang dimiliki masyarakat (empowering). Perkuatan ini meliputi langkahlangkah nyata, dan menyangkut penyediaan berbagai masukan (input), serta pembukaan akses ke dalam berbagai peluang (opportunities) yang akan membuat masyarakat menjadi berdaya.Ketiga, memberdayakan mengandung pula arti melindungi. Dalam proses pemberdayaan, harus dicegah yang lemah menjadi bertambah lemah, oleh karena kekurangberdayaan dalam menghadapi yang kuat. Oleh karena itu, perlindungan dan pemihakan kepada yang lemah amat mendasar sifatnya dalam konsep pemberdayaan masyarakat.

Tujuan umum dari pelatihan transfer teknologi yang di lakukan pada masyarakat Desa Wanayasa yaitu a) Untuk mengembangkan dan menambah keahlian yang dimiliki yang dimiliki masyarakat. b) Untuk mengembangkan pengetahuan masyarakat mengenai pemanfaatan sampah organik sehingga memiliki nilai guna bagi lingkungan dan menambah penghasilan dan mengurangi pengeluaran untuk pembelian pupuk untuk kepentingan pertanian. c) Untuk mengembangkan sikap, sehingga menimbulkan kerja sama dengan orang lain. Pemanfaatan sampah organik yang dibuat pupuk cair salah satunya sangat bermanfaat 
untuk mengurangi pencemaran lingkungan. Penggunaan pupuk cair dalam jangka panjang dapat memperbaiki sifat fisik, kimia dan biologi tanah. Pupuk cair mudah dibuat dan teknologinya sederhana.

\section{TINJAUAN PUSTAKA}

\section{Konsep Pemberdayaan}

Pemberdayaan adalah salah satu fokus dari pekerjaan sosial. Pemberdayaan adalah sebuah proses dan tujuan (Ife, 1995; Suharto, 2010:82). Makna pemberdayaan sebagai tujuan, yakni keberdayaan, sejatinya adalah indikator keberhasilan pemberdayaan sebagai suatu proses dari kerbedayaan mereka yang menyangkut kemampuan ekonomi, kemampuan mengakses manfaat kesejahteraan sosial dan kemampuan kultur dan politis.

Konsep pemberdayaan dalam wacana pembangunan masyarakat selalu dihubungkan dengan konsep mandiri, partispasi, jaringan kerja, dan keadilan. Pada dasarnya, pemberdayaan diletakkan pada kekuatan tingkat individu dan sosial. Menurut McArdle (1989) dalam (Hikmat, 2013:3) mengartikan pemberdayaan sebagai proses pengambilan keputusan oleh orangorang yang secara konsekuen melaksanakan keputusan tersebut. Orang-orang yang telah mencapai tujuan kolektif diberdayakan melalui kemandiriannya, bahkan merupakan "keharusan" untuk lebih diberdayakan melalui usaha mereka sendiri dan akumulasi pengetahuan, keterampilan serta sumber lainnya dalam rangka mencapai tujuan mereka tanpa bergantung pada pertolongan dari hubungan eksternal.

Dalam upaya memberdayakan masyarakat dapat dilihat dari tiga sisi, yaitu (Sumodiningrat, 2002); pertama, menciptakan suasana atau iklim yang memungkinkan potensi masyarakat berkembang (enabling). Disini titik tolaknya adalah pengenalan bahwa setiap manusia, setiap masyarakat, memiliki potensi yang dapat dikembangkan. Artinya, tidak ada masyarakat yang sama sekali tanpa daya, karena jika demikian akan sudah punah. Pemberdayaan adalah upaya untuk membangun daya itu, dengan mendorong, memotivasikan, dan membangkitkan kesadaran akan potensi yang dimilikinya serta berupaya ntuk mengembangkannya.

Kedua, memperkuat potensi atau daya yang dimiliki masyarakat (empowering). Perkuatan ini meliputi langkah-langkah nyata, dan menyangkut penyediaan berbagai masukan (input), serta pembukaan akses ke dalam berbagai peluang (opportunities) yang akan membuat masyarakat menjadi berdaya. Pada pemberdayaan disini dimana potensi ada sumber daya yang dimiliki oleh masyarakat ditonjolkan atau diperkuat. Potensi dan sumber daya yang ada diperkuat agar ketika masyarakat menghadapi masalah yang ada dilingkungan nya, maka potensi dan sumber daya yang ada pada masyarakat akan membantu dalam penyelesaian masalah maka dari itu potensi dan sumber daya yang ada harus digali dan diperkuat.

Ketiga, memberdayakan mengandung pula arti melindungi. Dalam proses pemberdayaan, harus dicegah yang lemah menjadi bertambah lemah, oleh karena kekurangberdayaan dalam menghadapi yang kuat. Oleh karena 
itu, perlindungan dan pemihakan kepada yang lemah amat mendasar sifatnya dalam konsep pemberdayaan masyarakat.Pemberdayaan

$\begin{array}{rrr}\text { masyarakat bukan membuat } & \text { masyarakat } & \text { menjadi }\end{array}$ tergantung pada berbagai program pemberian (charity). Karena, pada dasarnya setiap apa yang dinikmati harus dihasilkan atas usaha sendiri (yang hasilnya dapat dipraktekkan dengan pihak lain). Dengan demikian tujuan akhirnya adalah memandirikan masyarakat, memampukan, dan membangun kemampuan untuk memajukan diri ke arah kehidupan yang lebih baik secara berkesinambungan.

\section{Konsep Pengelolaan Sampah}

Sampah adalah barang yang dianggap sudah tidak terpakai dan dibuang oleh pemilik/pemakai sebelumnya, tetapi bagi sebagian orang masih bisa dipakai jika dikelola dengan prosedur yang benar.(Panji Nugroho, 2013). Penumpukan sampah disebabkan oleh beberapa faktor, diantaranya adalah volume sampah yang sangat besar sehingga melebihi kapasitas daya tampung tempat pembuangan sampah akhir (TPA). Pengelolaan sampah yang terjadi selama ini dirasakan tidak memberikan dampak positif kepada lingkungan, dan kuranganya dukungan kebijakan dari pemerintah.

Menurut Suhatro

mengatakan pemerintah belum begitu serius dalam memikirkan masalah sampah ini. Meski pemerintah sudah melakukan beberapa terobosan namun di beberapa tempat pembuangan sementara (TPS) gunungan sampah masih sangat mengganggu masyarakat dan masih menjadi perhatian.

Permasalahan sampah merupakan hal yang krusial (sulit terselesaikan). Bahkan, dapat diartikan sebagai masalah kultural/kebiasaan karena dampaknya mengenai berbagai sisi kehidupan, terutama di kota besar. Mengutip dari buku Panduan Membuat Pupuk Organik Cair (Nugroho, 2013), setiap harinya sekitar 6000 ton sampah dihasilkan di kota Jakarta. Oleh sebab itu bila tidak ditangani secara benar, maka akan menimbulkan dampak seperti pencemaran air, udara, dan tanah yang mengakibatkan sumber penyakit. Pengelolaan sampah diantaranya dapat dimanfaatkan menjadi kompos organik yang didalamnya terkandung unsur hara yang dibutuhkan tanaman (Nugroho, 2013), perbaikan struktur tanah dan zat yang dapat mengurangi bakteri yang merugikan dalam tanah. Pupuk organik biasanya tidak meninggalkan residu/sisa dalam tanaman sehingga hasil tanaman akan aman bila dikonsumsi (Sastrawan, 2014). Jenis jenis sampah Menurut Panji Nugroho dalam buku Panduan Membuat Pupuk Kompos cair (2013), jenis-jenis sampah dapat digolongkan menjadi beberapa jenis, antara lain :

Berdasarkan sifatnya

a. Sampah organik

Sampah organik, yaitu sampah yang mudah membusuk seperti sisa makanan, sayuran, daundaun kering, dan sebagainya. Sampah ini dapat diolah lebih lanjut menjadi kompos yang berguna utuk menyuburkan tanaman. Sampah organik jenis sampah yang bisa mengalami pelapukan dan terurai menjadi 
bahan yang lebih kecil dan tidak bau.

b. Sampah anorganik

Sampah anorganik, yaitu sampah yang tidak mudah membusuk, seperti plastik wadah pembungkus makanan, kertas, plastik mainan, botol dan gelas minuman, kaleng, kayu, dan sebagainya. Sampah ini dapat dijadikan sampah komersial atau sampah yang laku dijual untuk dijadikan produk laiannya. Beberapa sampah anorganik yang dapat dijual adalah plastic wadah pembungkus makanan, botol dan gelas bekas minuman, kaleng, kaca, dan kertas.

\section{Prinsip Pengolahan Sampah}

Berikut adalah prinsip-prinsip yang bisa diterapkan dalam pengolahan sampah. Prinsip-prinsip ini dikenal dengan nama $5 \mathrm{M}$

(Nugroho, 2013), yaitu:

- Mengurangi (Reduce)

Mengurangi penggunaan barangbarang habis pakai yang dapat menimbulkan sampah. Karena semakin banyak barang terbuang maka akan semakin banyak sampah.Contohnya seperti mengurangi penggunaan barang yang tidak bisa didaur ulang, mengurangi penggunaan kantong plastik pada setiap barang belanjaan.

- Menggunakan kembali (Reuse)

Mengusahakan untuk mencari barang-barang yang bisa dipakai kembali, dan mengindari pemakaian barang-barang yang sekali pakai guna memaksimalkan umur suatu barang.Lalu, menggunakan kembali material atau bahan yang masih layak pakai. Contohnya seperti menggunakan kembali botol minum bekas plastik yang masih layak menjadi sebuah pot untuk menanam tanaman.

- Mendaur ulang (Recycle)

Selain mencari barang yang dapat dipakai kembali, dapat pula mencari barang yang dapat didaur ulang. Sehingga barang tersebut dapat dimanfaatkan bukan menjadi sampah.Pada prinsipnya, kegiatan ini memanfaatkan barang bekas dengan cara engolah materinya untuk digunakan lebih lanjut. Contohnya seperti pemanfaatan sampah organik yang bisa menjadi pupuk kompos, dan memanfaatkan barang bekas untuk menajdi sebuah kerajinan, dll.

- Mengganti (Replace)

Metode ini dapat dilakukan dengan melakukan pengamatan disekitar. Ganti barang sekali pakai dengan barang yang lebih tahan lama, serta menggunakan barang yang ramah lingkungan.Upaya ini dinilai dapat mengubah kebiasaan seseorang yang mempercepat produksi sampah. Contohnya adalah mengubah penggunaan kertas tisu dengan menggunakan sapu tangan, dll.

- Menghargai (Respect)

Metode ini menggunakan rasa kecintaan pada alam, sehingga akan menimbulkan sikap bijaksana sebelum memilih.Pada prinsip ini diharapkan agar setiap orang mempunyai kesadaran akan sampah, dapat memilah dan memilih sasuatu barang yang akan digunakan dan mencintai alam sekitarnya. Cara Pengolahan Sampah Pengolahan sampah erat kaitannya dengan masyarakat karena dari sampah 
tersebut akan hidup mikroorganisme penyebab penyakit (bakteri,pathogen, jadi sampah harus betul-betul dapat diolah agar tidak menimbulkan masalah.

Menurut Nugroho (2013), berbagai cara yang dapat mengurangi efek negatif dari sampah, antara lain :

1. Penumpukan

Metode ini dilakukan dengan cara menumpuk sampah sampai membusuk, sehingga dapat menjadi kompos.Sampah organik atau sampah dari dapur yang sudah tidak terpakai dapat diolah menjadi pupuk kompos maupun menjadi pupuk cair, yang dapat bermanfaat.

2. Pembakaran

Pembakaran merupakan cara yang sering dilakukan, bahkan diberbagai TPA metode ini kerap dipakai pemerintah, kelemahan metode ini adalah tidak semua sampah dapat habis dibakar.Maka dari itu ketika akan membakar sampah sebelumnya harus diadakannya penyotiran sampah, mana sampah yang mudah habis terbakar dan sampah yang memang tidak dapat habis walaupun dibakar.

3. Sanitary Landfill

Metode ini juga kerap digunakan pemerintah, cara penerapannya adalah dengan membuat lubang baru untuk mengubur sampah.Setiap sampah yang dikumpulkan biasanya akan dibawa oleh petugas kebersihan atau dibakar namun pada cara pengolahan ini sampah - sampah yang sudah terkumpul akan dikubur atau ditimbun didalam lubang yang sudah ada dan di akan ditutup kembali oleh tanah.

\section{Pengomposan}

Cara ini sangat dianjurkan karena berdampak positif dan menghasilkan barang bermanfaat dari sampah yang berguna bagi lingkungan dan alam.Pengomposan merupakan suatu proses perombakan dan stabilisasi bahan organik oleh mikroorganisme dalam keadaan lingkungan terkandali dengan hasil akhir berupa humus atau kompos.

\section{METODE}

Metode yang digunakan dalam kegiatan transfer teknologi ini yaitu pemberian materi dan demonstrasi. Materi yang disampaikan berupa proses pembuatan pupuk organik menjadi pupuk cair. Peserta menyimak paparan dari pemateri yang dilanjutkan dengan demonstrasi pembuatan pupuk cair. Alat-alat yang digunakan dalam pelatihan berupa hijauan/daundaunan/bonggol pisang, sekam padi, gula pasir, air, terpal, golok/pisau, ember dan cangkul.

Pelatihan ini diharapkan dapat menjadi salah satu solusi dalam menjawab persoalan kebersihan lingkungan yang selama ini menjadi persoalan menahun karena tidak ada solusi dalam mengatasi persoalan sampah. Pelatihan pembuatan pupuk cair juga diarahkan pemamfaatan sumberdaya yang ada dilingkungan masyarakat yang selama ini tidak terpakai untuk menjadi bahan baku pupuk organik.

Kelompok sasarannya yaitu para pengurus RW 04, petani dan ibuibu masyarakat RW 04. Disini sasarannya adalah petani karena memang sebagian besar warga yang 
memang tinggal di lingkungan RW 04 bekerja sebagai petani dan ibu - ibu yang ada di RW 04.

\section{HASIL DAN PEMBAHASAN}

\section{Pelaksanaan dan Penyelenggaraan} Pelatihan

Kegiatan pemberdayaan masyarakat berupa transfer teknologi tentang pembuatan cair adalah sebagai upaya memanfaatkan potensi lingkungan sekitar berupa sisa sampah organik. Warga RW 04 yang mengikuti kegiatan ini memperoleh pengetahuan tentang pembuatan pupuk cair. Pada pembuatan pupuk cair ini digunakan limbah bahan organik yang ada disekitar lingkungan RT 04, seperti dedaunan, bonggol pisang, jatuhan buahbuahan. Hasil yang dicapai berupa sosialisasi mengenai pengolahan sampah menjadi pupuk kompos dan pupuk cair yang biasa disebut sebagai MOL (Mikro Organisme Lokal) atau POC (Pupuk Organik Cair) dan sampah non- organik yang ada di sekitar lingkungan RW 04 dapat dijadikan media pengganti batu bata. Sosialisasi dan pelatihan tersebut diberikan oleh Dinas Lingkungan Hidup Kota Bandung (DLHKB) kepada masyarakat. Untuk membuat pupuk, perlu menyiapkan alat dan bahan berikut ini: Sampah organik, Cairan EM-4,Tetes tebu,Air bersih,Kantong plastik,Tong atau wadah besar lain.

Langkah membuat pupuk organik cair: Sebagai salah satu cara membuat pupuk cair dari limbah rumah tangga khususnya sampah organik, yaitu mengikuti empat langkah sederhana di bawah ini: a). Mempersiapkan bahan organik: dalam rangka menghasilkan pupuk organik berkualitas, Anda harus memilih bahan yang akan terlibat dengan cermat. Sampah organik yang tersusun atas sebagian besar senyawa organik sifatnya mudah ditemukan seperti dari limbah rumah tangga. Adapun contoh sampah organik yang baik untuk diolah menjadi pupuk ialah sisa sayur, makanan, maupun buah. b). Menyampurkan EM-4: Setelah dicincang, bahan oraganik perlu dicampur dengan cairan bioaktivator EM-4. Selain bertujuan untuk mempercepat proses pembusukan, senyawa ini juga mampu memperbaiki tekstur dan struktur tanah. Perlu diketahui bahwa senyawa EM-4 yang digunakan harus telah aktif dengan cara menyampurkan tetes tebu. Selain tetes tebu, dan gula pasir dan air. c). Menyimpan pupuk: Setelah bakal pupuk telah bercampur dengan EM4, maka sudah dapat menyimpannya untuk proses fermentasi. Penyimpanan ini dapat dilakukan dengan memasukkan pupuk ke dalam kantong plastik berlubang. Lalu, kantong plastik dimasukkan ke dalam wadah yang lebih besar seperti tong. Akhirnya, pupuk pun dapat disaring lagi sehingga bagian cairan yang diperoleh merupakan pupuk organik cair. Anda tidak perlu membuang bagian padat hasil penyaringan karena dapat dijadikan pupuk organik padat. Hal ini menunjukkan bahwa sampah organik tidak perlu dibuang sia-sia apalagi dihindari karena jijik sebab bisa dimanfaatkan kembali secara optimal

Dibawah ini adalah gambar kegiatan transfer teknologi berupa pemaparan materi dan pembuatan kompos dan pupuk cair di Desa Wanayasa. 


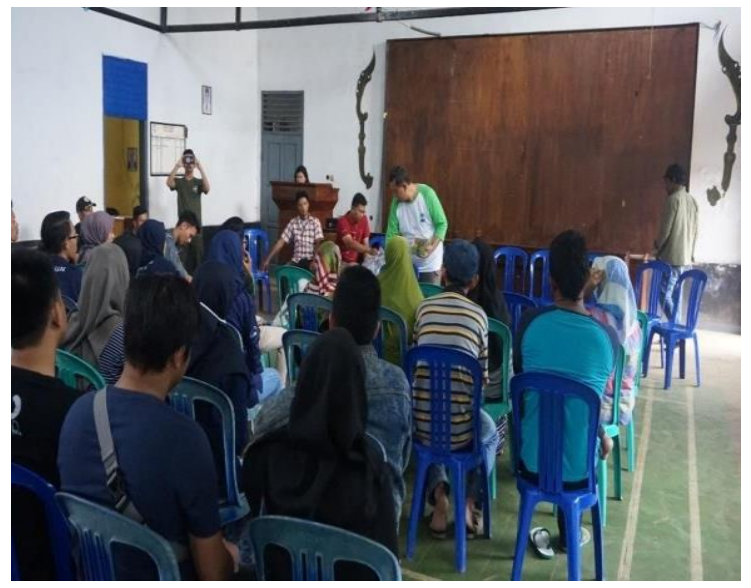

Gambar 1: Proses sosialisasi cara pembuatan pupuk cair di Balai Desa Wanayasa

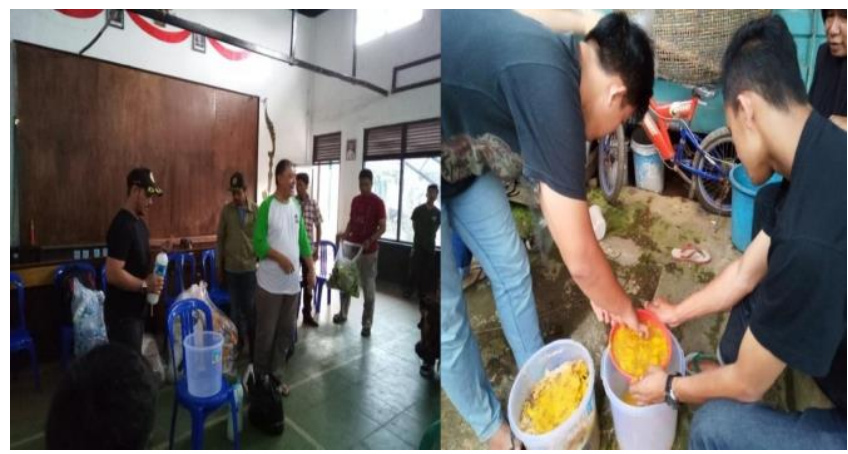

Gambar2 : Proses Pembuatan Pupuk Cair

Transfer teknologi pembuatan pupuk cair memberikan manfaat yang besar bagi warga RW 04 Desa Wanayasa yaitu adanya peningkatan pengetahuan tentang manfaat bahan sisa sampah organik sebagi bahan baku pembuatan pupuk cair. Sehingga diharapkan kedepannya warga RW 04 bisa membuat sendiri pupuk cair dari bahan-bahan organik yang ada disekitar mereka. Hal ini juga dalam rangka untuk mencapai kemandirian masyarakat untuk memanfaatkan potensi yang ada disekitar sebagai bahan baku pupuk cair untuk mendukung mewujudkan lingkungan yang bebas sampah serta untuk meningkatkan ketahanan ekonomi, karena dengan bisa membuat pupuk cair berarti bisa mengurangi pengeluaran untuk membeli pupuk untuk pertaniannya dan bisa juga untuk menambah pemasukan dengan membuat pupuk cair untuk dijual.

\section{Evaluasi}

Evaluasi dilakukan pada saat sebelum kegiatan, pada saat kegiatan sedang berlangsung dan kegiatan sudah selesai dengan cara evaluasi langsung terhadap semua peserta. Indikator keberhasilan dapat dilihat berdasarkan pemahaman peserta terhadap pupuk organik dan kemampuan peserta untuk dapat melakukan pembuatan pupuk cair. Peserta pelatihan diharapkan mampu mengidentifikasi bahan dan alat pembuatan pupuk cair, tahapan perlakuannya serta ketrampilan dalam membuat meramu bahan dan alat untuk menghasilkan pupuk cair. Secara garis besar, tujuan pelaksanan pelatihan berupa peningkatan pengetahuan sikap dan Ketrampilan masyarakat cukup memadai.

\section{Faktor Pendukung}

Mudah dan tersedianya bahan dan alat yang dibutukan untuk pelatihan pembuatan pupuk cair serta tempat pelatihan yang nyaman yang ada di Aula Desa Wanayasa sehingga menghadirkan kesan pelatihan berlangsung nyaman. Peserta merupakan pilihan dari masingmasing perwakilan RT yang ada di wilayah RW 04 yang menjadi utusan menurut hemat pelaksana peserta yang dikirim adalah mareka yang dianggap lebih cakap dari masing-masing masyarakt yang akan bisa mentranfer ilmunya kepada masyarakat lainnya. 


\section{Faktor penghambat}

Pada Pelaksanaan pelatihan Pembuatan Pupuk cair ini tidak mengalami hambatan yang berarti, baik dari sisi tehnis maupun non teknis, namun demikian waktu pelatihan sangat singkat sehingga materi pelatihan yang diberikan hanya bersifat pengenalan konsep dan cara pembuatan pupuk organik menjadi pupuk cair, mengingat terbatasnya dana pelatihan dan waktu pelatihan yang sangat singkat menyebabkan peserta harus mempraktikan ulang materi pelatihan di rumah masing-masing. Peserta dapat mempraktikkan secara langsung materi yang diajarkan saat pelatihan tanpa adanya control dari pelaksana.

\section{Simpulan}

Kegiatan pemberdayaan masyarakat di Desa Wanayasa melalui pelatihan pembuatan pupuk cair dalam rangka pemanfaatan sampah dapat menambahkan alternatif solusi untuk pemupukan tanaman petani disaat pupuk anorganik tidak diakses oleh petani karena keterbatasan modal yang dimiliki. Program pelatihan ini telah mendukung usaha peningkatan ekonomi masyarakat melalui pemanfaatan sumber daya lokal yang ada dilingkungannya. Melalui pelatihan pembuatan pupuk cair ini kembali memperkenalkan kepada masyarakat tentang konsep pertanian organik dan berkelanjutan sehingga lewat pelatihan peningkatan pengetahuan, sikap, ketrampilan masyarakat dapat kembali melirik cara budidaya yang ramah lingkungan.

\section{Saran}

Bagi peserta diharapkan dapat mengimplementasikan ilmunya yang didapatkan selama pelatihan untuk menghasilkan pupuk cair dan mengunakan dalam usahatani yang dikelolanya sekaligus menciptakan lingkungan bebas sampah. Masyarakat yang telah mendapatkan pelatihan pembuatan pupuk cair diharapkan dapat menularkan ilmunya kepada masyarakat yang lain di lokasi masing-masing. Kepada pihak pemerintah, dapat menggali potensi pembuatan pupuk cair sebagai peluang kerja dan mempunyai nilai ekonomis untuk meningkatkan pendapatan keluaraga dan mengurangi limbah sampah menjadi sesuatu yang bermanfaat serta menjaga kebersihan dan kesehatan lingkungan.

\section{Daftar Pustaka}

Iskandar, Jusman. 2017. Membangun Kekuatan Masyarakat. Cetakan Kelima Bandung: Puspaga

Setiawan, A.I. (2002). Memanfaatkan Kotoran Ternak. Cetakan ke tiga, Jakarta : Penebar Swadaya.

Suharto, Edi. 2014. Membangun Masyarakat Memberdayakan Rakyat. Cetakan Kelima.Bandung: PT Refika Aditama

Nugroho, Panji. 2013. Panduan Membuat Kompos Cair. Jakarta: Pustaka Baru Press Hikmat, Harry. 2013. Strategi Pemberdayaan Masyarakat: cetakan keenam. Bandung:Humaniora

Ign. Suharto. 2011. Limbah

Kimia dalam Pencemaran

Udara dan Air, Jakarta Suharto, Edi. 2009.

Pekerjaan Sosial Industri. Cetakan Kedua. Bandung: Alfabeta 
Suriwiria HU., (2002). Pupuk

Organik Komposdari

Sampah. Bioteknologi

Agroindustri.Bandung :

Humaniora Utama Press.

Moekijat. 1991. Latihan dan

Pengembangan Layanan Pegawai.

Bandung : Mandar Maju

Munawar Noor. 2011. Pemberdayaan

Masyarkat. Jurnal Ilmiah Civis.

Volume 1 No.2. Hal 87 - 88.

Khairul Akhir Lubis. 2008. Pengaruh

pelatihan dan Motivasi Kerja

Terhadap Kinerja Karyawan PT.

Perkebunan Nusantara.

Setiono. 2017. Jurnal semnas

ppm Vol 1, No 02

(2017)

http://ojs.universitasmuarabun

go.ac.id/index.php/PKITA/ind

ex

Arum Asriyanti Suhastyo. Jurnal

PPM ISSN: 2549-8347 (Online),

ISNN: 2579-9126 (Print) Volume 1

No. 2 September 2017 